\title{
When Legal Fictions Collide: The Primacy (OR OtherWISE) OF THE SEPARATE ENTITY PRINCIPLE OF CORPORATE LAW IN INTELLECTUAL PROPERTY CASES
}

\section{RHONDA CHESMOND*}

[Both "intellectual property" and "the corporation" can be and have been characterized as convenient legal fictions. Both also continue to be increasingly instrumental realities in the commercial world. This paper examines what happens when these two fictions collide - the issue of directors' and other officers' liability for intellectual property infringements by companies. Courts and commentators alike have generally advocated the primacy of the separate entity principle of corporate law in order to safeguard commercial enterprise and adventure. However, if intellectual property is viewed in accordance with its underlying justification, as a form of incentive necessary to promote new and useful innovations and creations, then any avoidance of responsibility by directors potentially undermines that incentive. In this event, the question must be posed as to whether the role and place of intellectual property in society warrants (or, indeed, receives) special treatment in cases involving companies infringing intellectual property rights.]

\section{INTRODUCTION}

Two recent Federal Court decisions in cases relating to peer to peer file sharing $^{1}$ and internet service providers ${ }^{2}$ have again raised the issue of director/officer liability for infringement of intellectual property rights by

\footnotetext{
${ }^{*}$ Research Fellow, Australian Centre for Intellectual Property in Agriculture (ACIPA), Griffith Law School, Griffith University. The author wishes to thank Dr Charles Lawson for his comments on an earlier draft of this paper.

${ }^{1}$ Universal Music Australia Pty Ltd v Sharman License Holdings Ltd (2005) 220 ALR 1.

2 Universal Music Australia Pty Ltd v Cooper (2005) 65 IPR 409.
} 
companies. Infringement of a person's intellectual property rights has long been considered tortious. ${ }^{3}$ If a company is alleged to have committed such a tort, then the question immediately arises as to the position of directors or other officers of the company ${ }^{4}$ acting for and on behalf of the company and whether it is possible for a plaintiff to take action against both the company and those individuals for the damage caused. A plaintiff may wish to do this for economic reasons, such as the perilous financial position of the corporate defendant, and in some cases, as a deterrent to other potential infringers. ${ }^{5}$

In a somewhat abstract sense this might be viewed as an encounter between two different convenient legal fictions: the corporation, and intellectual property rights. The importance of characterizing these concepts as fictions lies in the justifications given for their existence, principles, and efficacy. The more practical question to be explored is whether it can be said that the interests of one fiction does (or should) take precedence over the other at times when those interests compete.

This paper will briefly contemplate these familiar concepts as legal fictions. It will then examine the separate entity principle which has been central to corporate law theory, the clash of principle and policy behind the reasons for the courts' traditional reluctance to impose liability on directors generally for torts committed by companies, and the disparate approaches taken by courts to the issue. The paper also provides an analysis of recent intellectual property case law, in an attempt to establish whether a more unified approach to the issue of director liability for intellectual property infringements by companies is beginning to emerge.

Moreover, it is hoped that this paper may provide a starting point from which to analyse how the reasoning behind these cases fits into a broader theoretical framework about corporate law principle, policy and theory, and the

\footnotetext{
${ }^{3}$ WEA International Inc v Hanimex Corp Ltd (1987) 77 ALR 456, 465 (Gummow J); Microsoft Corporation and Another v Auschina Polaris Pty Ltd (1996) 142 ALR 111, 121; Kalamazoo (Aust) Pty Ltd v Compact Business Systems Pty Ltd (1985) 5 IPR 213, 258.

${ }^{4}$ From this point I refer only to directors of companies, both for convenience and because cases involving directors have been more prevalent. However, the considerations referred to throughout this paper apply equally to other company officers and employees. See Part 5.C below regarding the law on this issue. ${ }^{5}$ In the words of Wilcox J, ' the occasional legal proceeding may be useful pour encourager des autres'-see Universal Music Australia Pty Ltd v Sharman License Holdings Ltd (2005) 220 ALR 1, 87 [351].
} 
justifications for intellectual property. In other words, whether the role and place of intellectual property in society warrants (or receives) special treatment in cases involving companies infringing intellectual property rights. If it does, this poses some interesting challenges to those commentators asserting the primacy of the separate entity doctrine that may, in effect, allow companies to undermine the incentives provided by the intellectual property regime to innovate and create.

\section{Legal Fictions ANd OtheR 'TRANScendental Nonsense'}

Legal concepts (for example, corporations or property rights) are supernatural entities which do not have a verifiable existence except to the eyes of faith. ${ }^{6}$

A fiction is something which, although false, is accepted as true for the sake of convenience. ${ }^{7}$ Jurisprudence, as an autonomous system of legal concepts, rules and arguments, many of which rely on such fictions, was for legal realist, Felix Cohen, akin to 'a special branch of the science of transcendental nonsense'. ${ }^{8}$ This phenomenon might be better described as 'the metaphysical burden of social reality'. ${ }^{9}$ Searle points to social facts (in no way limited to the legal system) and explains:

[T]here are portions of the real world, objective facts, in the world, that are only facts by human agreement. In a sense there are things that exist only because we believe them to exist...these things are "objective" facts in the sense that they are not a matter of your or my preferences, evaluations, or moral attitudes. ${ }^{10}$

In a purely practical sense, the relationship of both 'intellectual property' and 'the corporation' to physical reality is problematic. For example, with regard to intellectual property, Litman comments that '[i]n the face of intellectual property's lack of "thingness", the law must supply alternative concepts to take the place of physical boundaries'. ${ }^{11}$ The strongest and most popular justification for intellectual property protection is a utilitarian argument based

${ }^{6}$ Felix S Cohen, 'Transcendental Nonsense and the Functional Approach' (1935) 35

(6) Columbia Law Review 809, 821.

${ }^{7}$ Compact Oxford English Dictionary ( $\left.3^{\text {rd }} \mathrm{ed}\right)$.

${ }^{8}$ Cohen, above n 6, 821.

${ }^{9}$ John R Searle, The Construction of Social Reality (1995)1.

${ }^{10}$ Ibid.

11 Jessica Litman, ‘The Public Domain’ (1990) 39 Emory Law Journal 965, 971-972. 
on providing incentives to create. ${ }^{12}$ The Lockean labour theory of property ${ }^{13}$ is familiar to intellectual property scholars - the justification for intellectual property rights being that 'society rewards labor with property purely on the instrumental grounds that we must provide rewards to get labor'. ${ }^{14}$ This concept of a 'reward' theory means that the property rights of authors and inventors are a convenient fiction that is justified only by the social utility of the whole intellectual property system. ${ }^{15}$

Similarly, the corporation has often been characterized as a legal fiction. ${ }^{16}$ Brennan J, in Northside Developments Pty Ltd $v$ Registrar-General, ${ }^{17}$ comments that '[a] company, being a corporation, is a legal fiction. Its existence, capacities and activities are only such as the law attributes to it'. ${ }^{18}$ Cohen, on the other hand, laments the fact that:

Nobody has ever seen a corporation...To be sure, some of us have seen corporate funds, corporate transactions, etc. ... But this does not give us the right to hypostatize, to "thingify" the corporation. ${ }^{19}$

Realist acerbity notwithstanding, the fictionalists firmly believe a corporation is nothing more than 'a creature of the state' and this view is consistent with and supported by the provisions of the Corporations Act 2001 (Cth) ${ }^{20}$ dealing with the creation of a new corporation in the form of a registered company. ${ }^{21}$

\footnotetext{
${ }^{12}$ Edwin C Hettinger, 'Justifying Intellectual Property’ (1989) 18 Philosophy and Public Affairs 31, 47.

${ }^{13}$ John Locke, The Second Treatise of Government, in Two Treatises of Government (1698), Chapter V.

${ }^{14}$ See generally Justin Hughes, 'The Philosophy of Intellectual Property’ (1988) 77 Georgetown Law Journal 287, 296.

${ }^{15}$ Henry C Mitchell, The Intellectual Commons - Toward an Ecology of Intellectual Property (2005) 5.

${ }^{16}$ R Austin and I Ramsay, Ford's Principles of Corporations Law $\left(12^{\text {th }}\right.$ ed, 2005) [2.080].

${ }^{17}$ (1990) 170 CLR 146.

${ }^{18}$ (1990) 170 CLR 146, 171.

${ }^{19}$ Cohen, above n 6, 811.

${ }^{20}$ Corporations Act 2001 (Cth), s 119.

${ }^{21}$ Austin and Ramsay, above n 16, [2.080]. Cf those theorists (principally the realists) who argue that incorporation is merely the formal recognition of a pre-existing social collective. For other theories of the corporation see generally George Gillligan, 'Company Law and the Regulation of Financial Services in the Twenty-First Century: A Socio-Legal Perspective’ (2001) 3 International and Comparative Corporate Law Journal 33, 36-37.
} 
We need not labour the point, as these legal fictions are familiar to us, and somewhat paradoxically, they are both increasingly essential commercial realities. But the question to be answered is how they interact when they are brought together in an adversarial sense.

\section{Company Law Doctrine and the Separate Entity Principle}

Essential to any discussion of the tension between company law and intellectual property(or tort law where a breach of intellectual property rights has occurred) is a brief explanation of the nature of the corporation and consequences of incorporation.

It is a fundamental principle of corporate law that a company is a juristic person separate and distinct from those who make up and/or control the company. ${ }^{22}$ The well known principles laid down in Salomon $v$ Salomon ${ }^{23}$ mean that an act performed or committed in the name of the company is regarded as its own act. It is said that those behind the company are protected by the 'corporate veil', a convenient metaphor which emphasizes the separate legal personality of the corporation. As a general rule, the courts have given primacy $^{24}$ to the separate entity principle so that it is not possible to look behind the corporate veil to hold personally liable the person who is the directing mind and will, or 'the moving spirit' ${ }^{25}$ of the company. The purpose of the separate entity principle is to encourage commercial enterprise and adventure and limit any unreasonable risks associated with company office; a fact alluded to by courts when faced with primacy issues in all areas. ${ }^{26}$

\footnotetext{
${ }^{22}$ The process of making an abstract idea real or concrete is known as reification. See Helen Anderson, 'The Theory of the Corporation and its Relevance to Directors' Tortious Liability to Creditors' (2004) 16 Australian Journal of Corporate Law LEXIS 1-72, 15.

${ }^{23}$ [1897] AC 22.

${ }^{24}$ Some commentators have suggested that such company law doctrines must be given primacy as such primacy is inherent in the very nature of company law - see $\mathrm{R}$ Grantham and C Rickett, 'Directors' Tortious Liability: Contract, Tort or Company Law?’ (1999) 62 Modern Law Review 133, 139.

${ }^{25}$ As described in Martin Engineering Co and Another v Nicaro Holdings Pty Ltd and Others (1991) IPR 241, 242; MCA Records Inc and Another v Charly Records Ltd and Others [2001] EWCA Civ 1441.

${ }^{26}$ For example Slade LJ in C Evans \& Sons Ltd v Spritebrand [1985] 2 All ER 415; Mentmore Manufacturing Co Ltd v National Merchandising Manufacturing Co Inc [1978] 89 DLR (3d) 195. See also G H L Fridman, 'Personal Tort Liability of Company Directors’ (1992) 5 Canterbury Law Review 41, 44.
} 
While courts have recognised that the corporate veil may be lifted in certain circumstances, the applicable legal principles are often difficult to disentwine from the surrounding metaphor. Adding to the conceptual complexity is the fact that the doctrine enshrined in Salomon is also connected to the nature of a director's liability under organic theory, ${ }^{27}$ explained by Lord Denning as follows:

Some of the people in the company are mere servants and agents who are nothing more than hands to do the work and cannot be said to represent the mind or will. Others are directors and managers who represent the directing mind and will of the company, and control what it does. The state of mind of these managers is the state of mind of the company and is treated by the law as such. ${ }^{28}$

This means that even though the company is a separate juristic person, it is unable to act other than through living persons and the director must act as the company. As a result, the director is in a unique position of being the embodiment or persona of the company with his mind being the mind of the company. ${ }^{29}$ Recent Australian intellectual property cases have recognised or applied $^{30}$ the organic theory. For example, as Finkelstein J states:

A corporation is an abstraction; a creature of statute. It can carry out acts only because the law attributes to the corporation certain actions of its directors and officers. Thus a corporation can interfere with the rights of a third party only when the acts constituting the unlawful interference are attributed to the corporation. ${ }^{31}$

It is this theoretical framework which causes the difficulties encountered by courts and commentators in determining whether and to what extent a director

\footnotetext{
${ }^{27}$ From Lennard 's Carrying Co Ltd v Asiatic Petroleum Co Ltd [1915] AC 705, 7134 in which Viscount Haldane LC referred to directors not as agents but as the company itself, a process known as "anthropomorphism"; see Anderson above n 22, 52.; For a general discussion see D Wishart 'Anthropomorphism Rampant: Rounding up Executive Directors' Liability' [1993] New Zealand Law Journal 175.

${ }^{28}$ HL Bolton (Engineering) Co Ltd v TJ Graham \& Sons Ltd [1957] 1 QB 159, 172

${ }^{29}$ See for example the comments of Lord Reid in Tesco Supermarkets Ltd $v$ Nattrass [1972] AC 153.

${ }^{30}$ Recent examples of the application of this principle are found in the decisions of Tamberlin J in Universal Music Australia Pty Ltd v Cooper (2005) 65 IPR 409 and Wilcox J in Universal Music Australia Pty Ltd v Sharman License Holdings Ltd (2005) 220 ALR 1, 101 [421].

${ }^{31}$ Root Quality Pty Ltd and Another v Root Control Technologies Pty Ltd and Others (2000) 177 ALR 231, 260 (Finkelstein J).
} 
should be personally liable for the acts and omissions of a company. ${ }^{32}$ One commentator has commented that in this area the law is 'trying to have it both ways, or to have its cake and eat it'): in some cases a director is treated as completely distinct from the company (as was the case in Salomon) and in others he is considered to be the personification of the company. ${ }^{33}$ However the purpose of organic theory is to attribute a mental state to a company, an inanimate entity with no mind or will, not to 'exculpate directors from liability, ${ }^{34}$. It is not a reason to deny personal liability of a director of a company to a creditor of that company.

\section{The PRIMACY QUeStion - COMPANy LAW THEORY AND THIRD PARTY DAMAGE}

While on occasion there may be sound policy reasons why liability should be imposed on directors personally for torts committed in the course of operating the company, prima facie, company law doctrines must necessarily be accorded primacy. While such a claim may seem imperialistic, such primacy is inherent in the very nature of company law. ${ }^{36}$

The question of personal liability of company directors for torts committed by corporations is a classic example of a clash of legal principle and has provided difficult questions of policy to be resolved by courts. At issue are the fundamental principles underpinning both tort law and corporate law: alterum non laedere, the principle that everyone is answerable for their tortious wrongs; and the separate legal entity doctrine in accordance with the principles laid down in Salomon $v$ Salomon. ${ }^{37}$ Courts have found it relatively easy to recognise the problems of principle and policy inherent in this area. ${ }^{38}$ The solution has proved more elusive. Hardie Boys $\mathrm{J}$ put the issue quite simply:

The problem that has vexed the common law courts in this area is that of respecting the doctrine of separate legal personality on the one hand and of allowing an adequate remedy on the other. ${ }^{39}$

\footnotetext{
${ }^{32}$ Anderson above n 22, 45.

${ }^{33}$ Fridman, above n 26,54.

${ }^{34}$ Ibid 59.

${ }^{35}$ Anderson above n 22, 54.

${ }^{36}$ Grantham and Rickett, above n 24,139.

${ }^{37}$ [1897] AC 22.

${ }^{38}$ For example Mentmore Manufacturing Co Ltd v National Merchandising

Manufacturing Co Inc (1978) 89 DLR (3d) 195, 202 (Le Dain J).

${ }^{39}$ Trevor Ivoryv Anderson [1992] 2 NZLR 517,525 (Hardie Boys J).
} 
Unfortunately, the courts have not been unified in their approach to the resolution of an obviously difficult conceptual issue. As Anderson has recently noted, there are many instances where courts have been reluctant to hold a director liable for the tortious acts of his company for fear of undermining the separate legal entity doctrine and the organic theory of corporate law. ${ }^{40}$ This is often because courts find that despite valid economic and social policy reasons for imposing responsibility on a director, a creditor's contract is with the company itself. ${ }^{41}$ Such arguments should not, of course, be relevant to the determination of intellectual property cases as third parties are invariably involuntary tort creditors with whom the company has no contract. $^{42}$ In other cases, courts have demonstrated an unrestrained willingness to completely overlook the separate entity principle to hold directors personally liable. One of the reasons for this disparity has been a lack of theoretical understanding by courts of the meaning of separate legal identity and limited liability as it relates to corporations, and the intersection of these principles with the law of torts. ${ }^{43}$

\section{AvenUes to LiabiLITY IN IP CASES}

So where does the general rule relating to the primacy of the corporate veil leave tort creditors wishing to take action against directors of a company which has infringed their intellectual property rights? What are the avenues which lead to directors' personal liability?

There is no doubt that a person who commits a tort himself will be primarily liable, whether a director of a company, employee or otherwise. As noted by the court in C Evans \& Sons Ltd $v$ Spritebrand: ${ }^{44}$

[A] director of a company will [not] escape personal liability to third parties for torts which he has personally committed through his own hand (or mouth) merely because he committed the tort in the course of carrying out his duties as a director of his company. He can escape personal liability for such torts no more than can an employee acting in the course of his employment for a company, or an agent acting in the course of his agency for a company.

\footnotetext{
${ }^{40}$ Anderson, above n 22, 16.

${ }^{41}$ Ibid 16-17.

${ }^{42}$ Ibid.

${ }^{43}$ Ibid 71 and generally for a comprehensive discussion of the theory of the corporation and its relevance to the area of tort liability of directors.

${ }^{44}$ [1985] 2 All ER 415, 419.
} 
In such a case, the infringing activity (whether under statute or at common law) must be examined, together with the facts which constituted infringement by the company, to determine if the director, in fact, participated in the activities to the required degree, or conducted those activities in person.

Similarly, a director will be found personally liable if the company was established for the express purpose of doing a wrongful act or if the use of the company was an abuse which justified lifting the corporate veil. ${ }^{45}$ But in circumstances where it is the company which actually commits the tort, the question arises as to what degree of involvement on the part of a director is necessary for him to be rendered personally liable along with the company. It is firmly established that the holding of an office in a company, such as that of director or managing director does not, of itself, render that office holder liable. ${ }^{46}$ However, courts have continuously grappled with exactly what principles are applicable in such cases: joint tortfeasance; authorisation pursuant to relevant intellectual property legislation $;{ }^{47}$ or other general law principles which have the effect of piercing the corporate veil.

In Australian intellectual property cases, guidance in this regard has come from the judgment of Gummow J in WEA International Inc v Hanimex Corp Ltd: ${ }^{48}$

Where the infringer is a corporation, questions frequently arise as to the degree of involvement on the part of the directors necessary for them to be rendered personally liable. Those questions are not immediately answered by principles dealing with "authorization" or joint tortfeasance. Rather, recourse is to be had to the body of authority which explains the circumstances in which an officer of a corporation is personally liable for the torts of the corporation. ${ }^{49}$

\footnotetext{
${ }^{45}$ Rainham Chemical Works Ltd v Belvedere Fish Guano Ltd [1921] 2 AC 465. See generally J H Farrar, 'The Personal Liability of Directors for Corporate Torts' (1997) 9 Bond Law Review 102, 105; Anderson above n 22, 19.

${ }^{46}$ Microsoft Corporation v Auschina Polaris Pty Ltd (1996) 142 ALR 111 at 121; C Evans \& Sons Ltd v Spritebrand [1985] 2 All ER 415, 329; King v Milpurrurru (1996) 66 FCR 474; Kalamazoo (Aust) Pty Ltd v Compact Business Systems Pty Ltd (1985) 5 IPR 213, 258.

${ }^{47}$ Such as Copyright Act 1968 (Cth) ss 36 and 101; Patents Act 1990 (Cth) s 13(1) but note that different considerations apply to the different legislation.

${ }^{48}$ (1987) 77 ALR 456.

${ }^{49}$ WEA International Inc $v$ Hanimex Corp Ltd (1987) 77 ALR 456, 475 (Gummow J referring to C Evan \& Sons Ltd v Spritebrand [1985] 2 All ER 415 and Kalamazoo (Aust) Pty Ltd v Compact Business Systems Pty Ltd (1985) 5 IPR 213).
} 
It is the 'body of authority' referred to by Gummow J which has been the subject of most judicial discussion and disagreement. However, the principles of joint tortfeasance and authorisation are also raised in cases seeking to examine directors' liability for corporate torts. All three areas are discussed below.

\section{A Joint Tortfeasance}

The statement of Gummow J quoted above has been referred to in numerous cases, especially with regard to the application of the principles of joint tortfeasance to the issue of director liability. ${ }^{50}$ For example, Beazley $\mathrm{J}$ in King $v$ Milpurrurru, ${ }^{51}$ agreed that the principles of joint tortfeasance were not applicable because the essence of joint tortfeasance is 'concerted action to a common end' ${ }^{52}$ In other words, it is not enough that two or more persons assisted in or concurred in or contributed to an act causing damage, there must be a common design or something in the nature of agreed common action. ${ }^{53}$ This notion does not fit easily with the liability of a director for the company's wrongs because the person who is the directing mind and will of the company is an embodiment of the company and his mind is the mind of the company. ${ }^{54}$

For these reasons the current approach of the English appellate courts ${ }^{55}$ which have developed a joint tortfeasors framework in the context of directors' liability ${ }^{56}$ has not found favour in Australia.

\footnotetext{
${ }^{50}$ For example in Microsoft Corporation v Auschina Polaris Pty Ltd (1996) 142 ALR 111, 121 (Lindgren J); King v Milpurrurru, (1996) 136 ALR 327; Universal Music Australia Pty Ltd v Sharman License Holdings Ltd (2005) 220 ALR 1; Universal Music Australia Pty Ltd v Cooper (2005) 65 IPR 409.

${ }^{51}$ (1996) 136 ALR 327, 344-5.

52 The "Koursk" [1924] P 140, 159-60 cited with approval in Australia in International Inc v Hanimex Corp Ltd (1987) 77 ALR 456; Thompson v Australian Capital Television Pty Ltd (1996) 141 ALR 1, King v Milpurrurru, (1996) 136 ALR 327; Universal Music Australia Pty Ltd v Sharman License Holdings Ltd (2005) 220 ALR 1; Universal Music Australia Pty Ltd v Cooper (2005) 65 IPR 409.

${ }^{53}$ WEA International Inc v Hanimex Corp Ltd (1987) 77 ALR 456; Universal Music Australia v Cooper (2005) 65 IPR 409, 438 [135].

${ }^{54}$ King v Milpurrurru (1996) 136 ALR 327, 344-5 (Beazley J referring to comments by Lord Reid in Tesco Supermarkets Ltd v Nattrass [1972] AC 153, 170-1).

${ }_{55}$ A recent example is the decision in MCA Records Inc and Another $v$ Charly Records Ltd and others [2001] EWCA Civ 1441 applying intellectual property cases such as CBS Songs v Amstrad [1988] 2 All ER 484 and Unilever plc v Gillette (UK) Ltd [1989] RPC 583.

${ }^{56}$ See generally D Debenham, 'Return to the Beaten Path?: Directors' and Employees’ Liability for Intellectual Property Torts after Mentmore’ (2003)16.
} 
Recently, in the case of Universal Music Australia Pty Ltd $v$ Cooper ('Cooper')," Tamberlin J, after considering the authorities on joint tortfeasors, concluded that there was not sufficient common design established as between the parties in question to make them liable in respect of their participation in the infringement. At issue was whether, inter alia, a director and an employee of an incorporated internet service provider had shown a sufficient degree of common design or concerted action to make them joint tortfeasors either with internet users, or the owner/operator of the MP3S4FREE website who was found to have infringed various sections of the Copyright Act 1968 (Cth). ${ }^{58}$

In Universal Music Australia Pty Ltd $v$ Sharman License Holdings Ltd ('Sharman'), ${ }^{59}$ while not deciding the issue of director liability on the basis of joint tortfeasance, Wilcox $\mathrm{J}$ found that all respondents liable for authorisation of the infringement of the applicants' copyright were liable both individually and as joint tortfeasors pursuant to a common design. ${ }^{60}$

Generally, in Australia, courts have determined the liability of directors or officers of a company by reference either to authorisation, or by applying the various general law tests of director liability for torts of a company.

\section{B Authorisation}

Where it is alleged that a company, together with a director or other officer of the company, authorised the infringing acts pursuant to the relevant intellectual property legislation, those individuals will be primarily liable. ${ }^{61} \mathrm{In}$ that event it is necessary to determine the precise meaning of 'authorise'. It is beyond the scope of this paper to canvas in any depth the increasingly substantial issues relating to authorisation. ${ }^{62}$

Intellectual Property Journal 527, 530 who refers to this approach as 'a beacon of appellate guidance' in a very difficult area of law.

57 (2005) 65 IPR 409, 438 [134]-[137].

${ }^{58}$ In Cooper, the court did find that the director and employee were liable under the authorisation provisions of the legislation.

59 (2005) 220 ALR 1.

${ }^{60}$ Universal Music Australia Pty Ltd v Sharman License Holdings Ltd (2005) 220

ALR 1, 112 [489].

${ }^{61}$ Note however the view of Gummow J in WEA $v$ Hanimex (1987) 77 ALR 456 that the concept of "authorisation" in the Copyright legislation had its own independent operation from primary infringement and that approach was endorsed by a Full Court in Australasian Performing Right Association Ltd v Jain (1990) 26 FCR 53, 57.

62 The law of authorisation in Australia is referred to by the principles set out in Moorhouse v University of New South Wales [1976] RPC 151. 
In such cases, courts are called on to consider whether the acts of a director or officer procuring his company to infringe a copyright or patent could amount to an 'authorisation' or whether the 'authorisation' would only be by the company itself. ${ }^{63}$ If the authorisation is found only to have been made by the company as the director's action falls short of the necessary requirements, then courts must still return to general principles set out above to examine if the director is liable for procuring or directing the company to authorise the infringement.

In Sharman's case, liability was imposed in circumstances where individual directors or officers were shown to have been personally involved, in a deliberate and continuing way, in the company's authorisation of infringing conduct. ${ }^{64}$

It is interesting to note the differences in approach between the Sharman and Cooper cases on this issue. In Cooper, the court examined the principles of joint tortfeasance and authorisation under the Copyright Act 1968 (Cth), concluding that joint tortfeasance was not established on the evidence, but authorisation was quite clearly shown on the part of the director and employee of the corporate internet service provider, E-Talk/Com-Cen. The director and employee were found personally liable for authorisation as a result of their knowledge of, and failure to prevent, the breach. It was through this knowledge of the director that the company was made liable for authorisation as the director was the controlling mind of the company. ${ }^{65}$ This is an example of the correct application of the organic theory of corporate law.

\section{General law principles}

Three tests ${ }^{66}$ have evolved from cases where courts have sought to determine the personal liability of directors for the tortious conduct of the companies for

\footnotetext{
${ }^{63}$ Root Quality Pty Ltd and Another v Root Control Technologies Pty Ltd and Others (2000) 177 ALR 231, 268.

${ }^{64}$ Universal Music Australia Pty Ltd v Sharman License Holdings Ltd (2005) 220

ALR 1, 105 [444].

65 Universal Music Australia Pty Ltd v Cooper (2005) 65 IPR 409, 437 [130].

${ }^{66}$ It is thought that the principles extracted from the cases preferring the "assumption of liability" test, although considered and reviewed by courts dealing with intellectual property infringements, are quite limited in their application to the area of the tort of negligence and therefore will not be discussed here. See for example the comments of Finkelstein J in Root Quality Pty Ltd and Another v Root Control Technologies Pty Ltd and Others (2000) 177 ALR 231, 265.
} 
which they act. Many, but not all cases involve torts relating to intellectual property infringements and precedents are drawn from several Commonwealth jurisdictions.

The approach taken by Finkelstein J in Root Quality Pty Ltd and Another v Root Control Technologies Pty Ltd and Others ('Root Quality') ${ }^{67}$ has been noted as a fourth test in this area ${ }^{68}$ However, it is submitted that while the foundation of this approach is a different, the end result of Finkelstein J's analysis is based on the earlier tests. ${ }^{69}$

In any event, the fact that so many tests have evolved demonstrates the unsettled nature of this area of law. Anderson argues that this is because of the unresolved tensions between tort law and company law, combined with a lack of theoretical consistency and understanding by the courts. ${ }^{70}$ Similarly, Farrar is of the view that the courts have 'fumbled' with the vague and questionable tests, and doubts their efficacy. ${ }^{71}$ Each of the tests has been applied in Australia, and each has been criticized by Australian courts. Unfortunately, even at this point in time, the authorities differ on which test should be applied.

\section{The 'direct or procure' test}

The first test to evolve, and the test widely understood to be the easiest test to establish a director's person liability, was the 'direct or procure' test. The test is attributed to Atkin J in Performing Right Society Ltd $v$ Ciryl Theatrical Syndicate Ltd ('Performing Right Society') ${ }^{72}$ and has been employed by cases in the United Kingdom $^{73}$ and Australia, ${ }^{74}$ in many instances involving intellectual property infringement.

${ }^{67}$ Ibid.

${ }^{68}$ See generally Anderson, above n 22, 39 - 40.

${ }^{69}$ The "make the tort his own test". See Part V.C.2 below.

${ }^{70}$ Anderson above n 22, 2-3.

${ }^{71}$ Farrar above $n$ 45, 111.

${ }^{72}$ [1924] 1 KB 1, expanding on Lord Buckmaster's dictum in Rainham Chemical Works Ltd v Belvedere Fish Guano Ltd [1921] 2 AC 465.

${ }^{73}$ For example, Performing Right Society Ltd v Ciryl Theatrical Syndicate Ltd [1924]

1 KB 1; C Evans \& Sons Ltd v Spritebrand [1985] 2 All ER 415.

${ }^{74}$ Kalamazoo (Aust) Pty Ltd v Compact Business Systems Pty Ltd (1985) 5 IPR 213; Australasian Performing Right Association v Jain (1990) 26 FCR 53; Martin Engineering Co v Nicaro Holdings Pty Ltd (1991) 20 IPR 241; Microsoft Corporation $v$ Auschina Polaris Pty Ltd (1996) 71 FCR 231; Henley Arch Pty Ltd v Clarendon Homes (Aust) Pty Ltd (1998) 41 IPR 443; Autocaps (Aust) Pty Ltd v Pro-Kit Pty Ltd; (1999) 46 IPR 339; the test also had the support of Lee J (dissenting) in Milpurrurru 
The court investigates whether a director expressly procured or directed the commission of the tort by the corporation. Whilst leaving open the degree of direction and procurement necessary before a director will be liable, the courts applying this test have expressly rejected the suggestion that a director must know or be reckless as to the possibility that the acts were wrongful. ${ }^{75}$ The cases suggest that if the directors were responsible for managing the company and directing the course the company followed at all material times, then they are equally liable with the company for the damage which flowed from the wrong.

This test has a substantial following in Australian intellectual property cases. ${ }^{76}$ Nevertheless, it has been criticised as irrational for imposing liability merely because the director expressly or impliedly directs the commission of the tortious act or conduct without something more, as in situations involving a one person company liability would be imposed in almost every case. ${ }^{77}$ In this regard, it is thought that this test does not give due consideration to the concept of the separate legal existence of the company or the fact that the corporation must act through its directors. ${ }^{78}$

Such criticism led to the evolution of the second test which requires a further step before directors will be held liable for the company's tortious acts.

\section{The 'make the tort his own' test}

This test is narrower than the 'direct or procure' test, making it more difficult for a director to be found personally liable. However, while courts have sought to justify the greater stringency in terms of policy, the test has been widely criticised as inadequate, uncertain in its meaning and scope, and circular in its reasoning. ${ }^{79}$

and others $v$ Indofurn and others (1994) 130 ALR 659 [agreeing with Von Doussa J at first instance].

${ }^{75}$ Performing Right Society Ltd v Ciryl Theatrical Syndicate Ltd [1924] 1 KB 1; C Evans \& Sons Ltd v Spritebrand [1985] 2 All ER 415; Kalamazoo (Aust) Pty Ltd v Compact Business Systems Pty Ltd (1985) 5 IPR 213.

${ }^{76}$ refer to $n 75$.

${ }^{77}$ White Horse Distilleries Ltd v Gregson Associates Ltd [1984] RPC 61 (Nourse J).

${ }^{78}$ King v Milpurrurru (1996) 136 ALR 327, 350 *(Beazley J).

${ }^{79}$ See for example Debenham above n 56, 527-8 and Farrar above n 45, 108; see also Microsoft v Auschina Polaris (1996) 142 ALR 111, 124 (Lindgren J); Universal Music Australia Pty Ltd v Sharman License Holdings Ltd (2005) 220 ALR 1, [434] (Wilcox J). 
The test originated in Canada with the decision in Mentmore Manufacturing Co Ltd v National Merchandising Manufacturing Co Inc ('Mentmore'), ${ }^{80}$ a patent infringement case where the plaintiff sought to hold an individual who was the president and principal shareholder of the company personally liable for the infringement together with the company. On appeal to the Federal Court of Appeal Le Dain J looked closely at the issue and asked:

What...is the kind of participation in the acts of the company that should give rise to personal liability? It is an elusive question. It would appear to be that degree and kind of personal involvement by which the director or officer makes the tortious act his own. It is obviously a question of fact to be decided on the circumstances of each case. ${ }^{81}$

The court dismissed the action against the individual president on the grounds that the evidence did not establish that he 'deliberately or recklessly embarked on a scheme, using the company as a vehicle, to secure profit or custom which rightfully belonged to the plaintiffs' ${ }^{82}$ Although Le Dain J said that '[r]oom must be left for a broad appreciation of circumstances of each case to determine whether as a matter of policy they call for personal liability', ${ }^{83}$ what appears to be required to render a director personally liable for torts with no mens rea requirement such as intellectual property infringement, is deliberate conduct outside the ordinary management of the company's affairs which is likely to constitute infringement, or an indifference to the risk of infringement. In Mentmore, the fact that the directors in question imparted practical, business, financial and administrative policies and directives which led to the assembly and sale of the infringing goods was not enough to impose personal liability. This can be contrasted with the 'direct or procure' test, which merely requires personal involvement in the operation of the company.

The Mentmore decision has been followed widely in intellectual property cases in Canada, ${ }^{84}$ including, interestingly, the epic Monsanto v Schmeiser ${ }^{85}$

${ }^{80}$ (1978) 89 DLR (3d) 195.

${ }^{81}$ Ibid 203 (Le Dain J).

${ }^{82}$ Ibid 204.

${ }^{83}$ Ibid 205.

${ }^{84}$ Visa International Service Association v Visa Motel Corp [1984] 1 CPR (3d) 109; Hirsh Co v Spacemaker Ltd [1987] 17 CPR (3d) 89; TNT Canada Inc v Kwik Transfer Inc [1987] 18 CPR (3d) 51; Windsurfing International Inc v Novaction Sports Inc [1987] 18 CPR (3d) 230; Hirsh Co v Minshall [1988] 89 NR 136; 22 CPR (3d) 268; and Katun Corp v Technofax Inc [1988] 22 CPR (3d) 269; Prism Hospital Software Inc v Hospital Medical Research Institute [1988] 18 CPR(3d) 398,401.

${ }^{85}$ Monsanto Canada Inc et al v Schmeiser et al 2001 FCT 256. 
litigation. The test has also had a judicial following in the United Kingdom, ${ }^{86}$ and Australia. ${ }^{87}$

The 'make the tort his own' test has been the subject of criticism by courts preferring the 'direct or procure test' on the basis that it is questionable whether 'flexible considerations of policy would be capable of overriding the basic principles of liability according to the facts of the particular case, ${ }^{88}$

Nevertheless, like the 'direct or procure' test, this test has also found favour in Australia. In King $v$ Milpurrurru, ${ }^{89}$ a breach of copyright case involving sections 36 and 37 Copyright Act 1968 (Cth), the Full Court of the Federal Court preferred the view that a director will only be liable for the company's breach of those sections where he commits, or directs the commission of the tort, deliberately or recklessly, so as to make the tortious conduct his own. Interestingly, the majority held that even where the directors' conduct is such as to constitute a breach of duty ${ }^{90}$ to the company, such conduct is insufficient to render directors liable to third parties.

In that case, the company was found at first instance ${ }^{91}$ to have breached s 37 of the Copyright Act 1968 (Cth) when it imported for sale carpets which reproduced the respondents' paintings. The managing director and the two appellants, who were both directors, but had played no part in the management of the company, were also found liable for copyright infringement. It was found by the trial judge that the degree of indifference exhibited by the appellants to the allegations of copyright infringement constituted authorisation or permission by them to the company's continued importation of the carpets. A majority of the Federal Court of Appeal held that the appeal should be allowed as the appellants' failure to make adequate enquiries and breach of duty to the company did not support the conclusion that they should be personally liable to a third party.

\footnotetext{
${ }^{86}$ White Horse Distilleries Ltd v Gregson Associates Ltd [1984] RPC 61.

${ }^{87}$ King v Milpurrurru (1996) 136 ALR 327; Universal Music Australia Pty Ltd v Sharman License Holdings Ltd [2005] FCA 1242 (5 September 2005); Root Quality Pty Ltd and Another v Root Control Technologies Pty Ltd and Others (2000) 177 ALR 231.

${ }^{88}$ C Evans \& Sons Ltd $v$ Spritebrand Ltd and another [1985] 2 All ER 415 at 423.

${ }^{89}$ King and Another v Milpurrurru and Others (1996) 136 ALR 327 (Jenkinson and Beazley JJ, Lee J dissenting).

${ }^{90}$ The duty to take reasonable steps to prevent the company from committing serious breaches of the type alleged. Corporations Act 2001 (Cth) ss 180 and 181 are relevant.

${ }^{91}$ Milpurrurru v Indofurn Pty Ltd (1994) 130 ALR 659 (Von Doussa J).
} 
In the course of her judgment, Beazley $\mathrm{J}$ reviewed the English, Canadian and New Zealand decisions and concluded that the principles stated in Performing Right Society ${ }^{92}$ did not pay sufficient heed either to the separate legal existence of the corporation or to the fact that the corporation acts through its directors. Her Honour agreed with the criticism of those decisions by Nourse $\mathrm{J}$ in White Horse Distilleries Ltd $v$ Gregson Associates $L t d^{93}$, finding the Mentmore line of authority a more satisfactory approach.

By way of contrast, in Microsoft Corporation v Auschina Polaris Pty Ltd, ${ }^{94}$ Lindgren J expressly disagreed with the approach of Beazley J, adopting the 'direct or procure' test to find a director personally liable and stating:

I find the 'directed or procured' test more satisfactory than the 'making the tortious act his own' test. In any event, the former test is supported by Australian authority which I should follow unless convinced that it is clearly wrong. I am not convinced that it is clearly wrong. ${ }^{95}$

In that case, the company was liable for the importation and sale of unlicensed computer software and the director was the only individual who played any role in relation to the acquisition, importation and onsale of the infringing copies of the computer programs. Lindgren $\mathrm{J}$ was of the view that although the evidence did not go so far as to establish 'the deliberate, willful and knowing pursuit of a course of conduct that was likely to constitute infringement or reflected an indifference to the risk of it ${ }^{96}$ according to the Mentmore principles, the fact that the director in question was alone totally responsible for all the elements of the infringements provided for in ss 37 and 38 of the Copyright Act 1968 (Cth) which rendered the company liable, was sufficient to render him liable for those infringements also. ${ }^{97}$

Judicial disagreement aside, any court which prefers the 'make the tort his own' test will find that personal liability for a company's torts can only be attributed to directors in circumstances where their deliberate or reckless conduct otherwise distinguishes them from their role as the directing mind and will of the company.

${ }^{92}[1924] 1$ KB 1.

${ }^{93}$ [1984] RPC 61.

${ }^{94}$ Microsoft Corporation and Another v Auschina Polaris Pty Ltd and Others (1996)

142 ALR 111.

${ }_{95}$ Ibid 125.

${ }_{97}^{96}$ Mentmore, 204-5 (Le Dain J).

${ }^{97}$ Ibid. 


\section{The rule in Said v Butt - The Root Quality approach}

In the relatively recent decision of Root Quality ${ }^{98}$ Finkelstein $\mathrm{J}$ referred to the body of authority set out in the tests above as founded on the principles established by Lumley $v$ Gye. ${ }^{99}$ This is the case upon which the modern formulation of the tort of procuring the violation of the legal rights of another is based. ${ }^{100}$

Finkelstein J found fault with all the traditional tests, and in particular with the decisions based on the 'direct and procure' test, noting that they do not properly confront the nature of corporate personality and liability of a corporation for the acts of its agents. One of the foundations for Finkelstein J's judgment was the rule in Said $v$ Butt, ${ }^{101}$ which originally applied to the tort of procuring a breach of contract and is based on recognition of the fact that the deliberate actions of the director in extricating his company from a contract may be in the company's best interests. In these circumstances courts consider personal liability undesirable as there is no bad faith in procuring the company to breach its contract, because it is preferable for the company to pay damages for breach of contract rather than to honour the contract. ${ }^{102}$ Finkelstein $\mathrm{J}$ relied on authority that the tort is not confined to interference with contracts but extends to all wrongful acts done intentionally which damage a particular individual. ${ }^{103}$ The rule's application therefore, was found to extend to the alleged patent infringement in Root Quality.

The effect of this extended application of the rule in Said $v$ Butt, which Finkelstein J expressly found represents the law in Australia, is that a director or officer acting in that capacity could not be found liable for procuring his corporation to infringe the rights of another. ${ }^{104}$ However, the court also relied on authority which confirmed that it does not necessarily follow that a director of a company would escape personal liability under cover of the company's responsibility if he became 'an actor' in invading the plaintiff's rights. ${ }^{105}$

\footnotetext{
98 (2000) 177 ALR 231.

99 [1853] 118 ER 749.

${ }^{100}$ Root Quality Pty Ltd and Another v Root Control Technologies Pty Ltd and Others (2000) 177 ALR 231, 258.

${ }^{101}$ [1920] 3 KB 497 (McCardie J); referred to by McTiernan J in O’Brien v Dawson (1942) 66 CLR 18, 34; followed in Tsaprazis v Goldcrest Properties Pty Ltd (2000) 18 ACLC 285; Imperial Oil Ltd v C \& G Holdings Ltd [1990] 62 DLR (4th) 261.

${ }^{102}$ Anderson above n 22, 41.

${ }^{103}$ Root Quality Pty Ltd and Another v Root Control Technologies Pty Ltd and Others (2000) 177 ALR 231, 258.

${ }^{104}$ Ibid 262.

${ }^{105}$ Ibid, based on the reasoning of Starke J in O'Brien v Dawson (1942) 66 CLR 18.
} 
This assumption that personal liability in tort is possible for procuring an interference with legal rights led Finkelstein $\mathrm{J}$ to examine the issue of whether such personal liability undermines the principles of separate corporate personality and he analysed the tests referred to above on that basis. His Honour rejected the Performing Right Society 'direct or procure' test, but also appeared uncomfortable with the Mentmore line of authority ${ }^{106}$ as it would not always be easy to identify the circumstances under which a director could 'make the tort his own'. Ultimately he concluded:

All that can be said confidently is that if a director decides that his company should carry out an act that results in an infringement of the rights of a third party, the director does not, without more, render himself personally liable... The director's conduct must be such that it can be said of him that he was so personally involved in the commission of the unlawful act that it is just that he should be rendered liable. If a director deliberately takes steps to procure the commission of an act which the director knows is unlawful and procures that act for the purpose of causing injury to a third party, then plainly it is just that liability should be imposed upon him. Lesser conduct may suffice. For example, if the director is recklessly indifferent as regards whether his company's act was unlawful and would cause harm, that may also suffice. In the end it will depend upon the facts of each particular case. Where the boundary lies, between the non-tortious conduct of a director who acts bona fide within the course of his authority and the tortious conduct of a director who acts deliberately and maliciously to cause harm, cannot be stated with any precision. ${ }^{107}$

This passage has recently been cited with approval by Wilcox $\mathrm{J}$ in Sharman, ${ }^{108}$ who agreed to adopt the approach because he believed it encapsulates the essence of the approach taken (even if not the language used) in many intellectual property cases decided by the Federal Court. ${ }^{109}$

\footnotetext{
${ }^{106}$ This was also noted by Wilcox J in Universal Music Australia Pty Ltd v Sharman License Holdings Ltd (2005) 220 ALR 1.

${ }^{107}$ Root Quality Pty Ltd and Another v Root Control Technologies Pty Ltd and Others (2000) 177 ALR 231, 268.

108 (2005) 220 ALR 1.

${ }^{109}$ Universal Music Australia Pty Ltd v Sharman License Holdings Ltd (2005) 220

ALR 1, 103 [434] referring to APRA v Jain (1990) 96 ALR 619; Microsoft v Auschina Polaris (1996) 142 ALR 111 and Universal Music Australia Pty Ltd v Cooper (2005) 65 IPR 409, [130].
} 


\section{$4 \quad$ Analysis of current position on general law tests}

Commentators agree that the reason for the establishment of so many tests is the courts' inadequate understanding of the theoretical issues underpinning this area. ${ }^{110}$ However, from a practical viewpoint, the question is whether an examination of the cases in Australia relating to intellectual property infringements points to a common application of principles by the courts for the imposition of director liability.

The predominance of authority in Australian intellectual property cases rests with both the 'direct and procure' test from Performing Right Society, and the 'make the tort his own' test derived from the Mentmore line of authority. ${ }^{111}$ Interestingly, some courts have found the distinction between the tests to be largely irrelevant. For example, in Allen Manufacturing Company Pty Ltd $v$ McCallum \& Co Pty Ltd ${ }^{112}$ the Full Federal Court noted that:

The difference between the two tests may be more apparent than real. We are not aware of any case in which it has been held that a director or officer of a company directed or procured the company's infringing act, yet that person escaped liability because he or she did not deliberately, wilfully or knowingly pursue a course of conduct that was likely to constitute infringement or that reflected indifference to the risk of infringement. This may be because, in practice, an act of direction or procurement will generally meet the Mentmore test. ${ }^{113}$

The court found that evidence did not show the relevant individual was merely acting as director of the company found liable for design infringement. Rather, he had personal knowledge of the registered design, applied for registration of the infringing design and granted a licence and accepted a sublicence to use the design.

Similarly in APRA v Metro On George Pty Ltd, ${ }^{114}$ Bennett $\mathrm{J}$ found in a copyright infringement case that one director (but not another) was liable 'under both the tests in Mentmore and in Performing Rights, to the extent that there is a difference between them'. ${ }^{115}$ The director found liable was found to

110 See generally Anderson above n 22; Fridman above n 26; Farrar above n 45.

${ }^{111}$ For this reason the further test of assumption of liability has not been discussed here.

112 [2001] FCA 1838 (20 December 2001).

113 Ibid [43] - [44].

114 (2004) 61 IPR 575.

115 Ibid 594. 
have ordered, directed or procured the company to carry on its infringing activities while pursuing a 'knowing, deliberate, willful ${ }^{116}$ course of conduct, indifferent to the risk of infringement.

It is possible that the courts are more recently preferring the Mentmore line of authority, or declining to decide on a test because the facts before them are sufficient to satisfy both tests. It does not appear currently to be the case that courts generally prefer the test with a higher standard to avoid imposing liability if that is the result they wish to achieve. ${ }^{117}$

Some common features have emerged from the cases. It seems that in cases where the director is the will or "the moving spririt" of a company, courts are more likely to find a director liable. In Martin Engineering Co v Nicaro Holdings Pty Ltd, ${ }^{118}$ Burchett $\mathrm{J}$ expressly found that the individual was 'a director and the moving spirit' of the companies and there was no doubt, on the evidence, that he was personally involved in the activities and authorised, directed and promoted the infringements. In Sharman, for example, the court found it was a combination of a director being intimately involved in the activities of the company, formulation or approval of its policies and generally being 'the boss'. 119

The most recent decisions of the Federal Court have demonstrated a preference for the Mentmore test, despite a general criticism that its meaning and scope are uncertain. ${ }^{120}$ Perhaps it is the principles of Mentmore rather than the wording of the test that attracts judicial agreement. As Wilcox J stated in Sharman, 'I prefer to eschew any catchphrase and consider the justice of the case'. ${ }^{121}$

Commentators ${ }^{122}$ have stated that an authoritative decision is needed on a test which is developed on the basis of an evaluation of the strengths and weaknesses of each present test while satisfying the policy issues relating to

\footnotetext{
${ }^{116}$ Mentmore, 203 (Le Dain J).

${ }^{117}$ Cf Farrar above n 45, 111.

118 (1991) 20 IPR 241.

119 Universal Music Australia Pty Ltd v Sharman License Holdings Ltd (2005) 220

ALR 1, 104 [439].

120 For example, ibid, 103 [434]; Microsoft v Auschina Polaris (1996) 142 ALR 111, 124.

${ }^{121}$ Universal Music Australia Pty Ltd v Sharman License Holdings Ltd (2005) 220

ALR 1,103 [434].

122 Such as Farrar above n 45, 111.
} 
the clash of fundamental principles. I would suggest that the Australian courts are at least moving closer to that goal and towards a test which requires a higher level of involvement in the infringing activity than simply the direction or procurement. The view of Finkelstein J in Root Quality may ultimately be the middle ground sought by courts and commentators in relation to this issue with its emphasis on what is just in the circumstances of the case:

If a director deliberately takes steps to procure the commission of an act which the director knows is unlawful and procures that act for the purpose of causing injury to a third party, then plainly it is just that liability should be imposed upon him. Lesser conduct may suffice. ${ }^{123}$

However, whether this approach in fact surmounts the problems relating to the meaning and scope of the Mentmore test is questionable.

\section{$5 \quad$ Application to non directors}

The principles set out above extend to individuals other than directors of companies. The intellectual property cases in this area accord with the view that a person need not be a director of a company to be personally liable for wrongs committed against a third party ; hence, any test applied by the courts can apply equally to directors, managers, employees or other officers of a company.

Branson J in Microsoft v Goodview Electronics Pty Ltd ${ }^{124}$ quoted Microsoft v Auschina Polaris ${ }^{125}$ with approval in finding an employee in control of a company liable for copyright breaches in accord with the policy rationale of holding individuals liable for a company's tortious acts. ${ }^{126}$

Most recently, Wilcox J in Sharman ${ }^{127}$ stated that he adopted the test of Finkelstein J in Root Quality, 'with the qualification that the person need not be a director of the company, ${ }^{128}$. And as Le Dain J stated in the Mentmore case: 'I do not think the question whether or not he was a director is important in so far as liability is concerned. It is what he actually did that matters. ${ }^{129}$

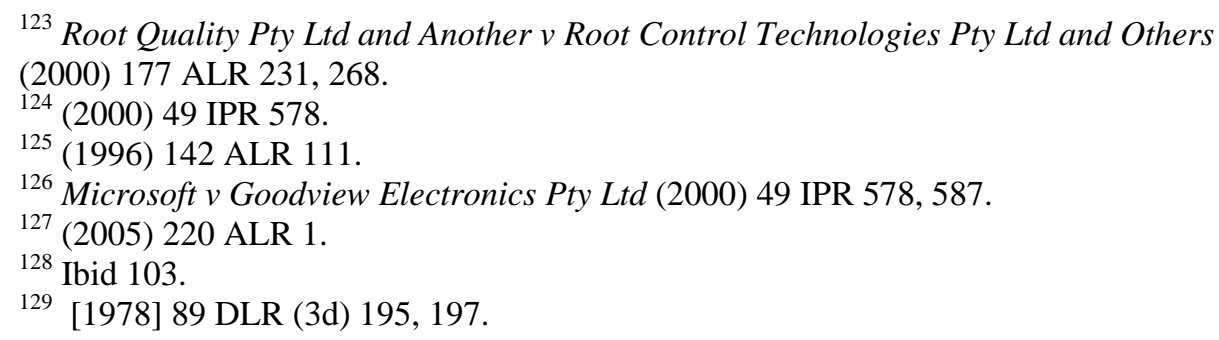




\section{CONCLUSION- IP RIghts V CORPORATE LAW PRINCIPLE}

It is now beyond question that a director does not enjoy a general immunity from liability by virtue of his position as a director. While it is obvious that a measure of caution is required so as not to discourage commercial enterprise and adventure by subjecting a director to overly onerous potential liabilities, it is equally obvious that a stage has been reached in corporate law and practice that requires a greater level of responsibility for actions by directors. More onerous corporate governance rules, directors' duties, ${ }^{130}$ liability for insolvent trading by companies, and the general community-fuelled push for greater corporate social responsibility makes this evolution inevitable. The corporate world has changed beyond recognition since the time of Salomon.

The rapid expansion of technology has also meant a surge in the importance and expanse of intellectual property law. There is an expectation by parties whose rights have been infringed that the law will allow them to recover adequate compensation and that punishments will be imposed on wrongdoers which are effective to deter potential infringers.

Commentators on the issue may continue to argue for the primacy of corporate law. ${ }^{131}$ However, it seems clear that in Australia, courts are willing to impose liability on directors for infringements by companies of third parties' intellectual property rights. The only unresolved issue is the route taken by the court in question to deal with the matter. On this practical point, the authorities continue to be in some disarray. Most recent authorities continue to refer to concepts of joint tortfeasance, authorisation and/or those other general law principles which lead to liability of directors. There is no consensus on the question of which test to apply when discussing these general principles. However, there does appear to be some movement by the Federal Court towards a test along the Mentmore line - a test which is more demanding than the 'direct or procure' principle, and one which follows the reasoning of Finkelstein J in Root Quality and Wilcox J in Sharman.

A more interesting aspect of this issue is whether this willingness to impose personal liability on directors is the result of a conscious (or unconscious) acknowledgement by the courts that any strict application of the separate

\footnotetext{
${ }^{130}$ Note that behaviour constituting breach of director's duties in relation to the infringing activities was thought sufficient to impose liability by both Lee J (dissenting) and Von Doussa J at first instance in the Milpurrurru case.

${ }^{131} \mathrm{Eg}$, Grantham and Rickett above n 24, 139.
} 
entity principle would undermine the incentive to create that underlies intellectual property theory and practice. There is no explicit indication by courts that the imposition of a stricter test for director liability is any way connected to the subject matter of the infringement in question.

In any event, it must be questioned whether this is reason enough to displace any primacy of company law theory which may have existed, at least in the absence of any more socially justifiable policy (such as that relating to cases involving injury to involuntary tort creditors). The incentive to commercial enterprise and adventure which underpins the separate entity principle must be considered to be equally important in economic terms.

In reality, the clash between policy and principle which underscores director liability in tort cases generally, and more particularly, the issue of company law principle and the incentive (or reward) theory which justifies intellectual property is more about balance than it is about competition or primacy. The overall impression created by the decision in Sharman ${ }^{132}$ is of the Federal Court's reluctance to shift the present balance of rights between intellectual property owners and intellectual property users. ${ }^{133}$ On this basis, it is difficult to assert with any confidence that intellectual property is obtaining, or indeed, deserving of special treatment - that if directors are not held responsible (where companies can avoid their liability for whatever reason), then the incentive provided by intellectual property rights will be undermined leading to less innovation and creation.

If there is only one certainty in this area of law at the present time, it is the fact that directors, officers and other employees of companies guilty of intellectual property infringement can expect to have their own actions carefully scrutinized by courts who are more willing than ever before to impose upon them personal liability for those actions. Whether that

\footnotetext{
${ }^{132}$ Universal Music Australia Pty Ltd v Sharman License Holdings Ltd (2005) 220 ALR 1.

133 Ibid 5. Wilcox J appeared to be sympathetic to the respondents' position saying “I understand the argument in favour of more widespread licensing of copyright works. No doubt that course would have commercial implications for sound recording distributors. Whether or not they should take it is a matter to be determined by them. Unless and until they do decide to take that course, they are entitled to invoke such protective rights as the law affords them.” And at [351] "it is not realistic to believe legal action against individual infringers will stamp out, or even significantly reduce, file-sharing infringements of copyright”.
} 
willingness relates to a judicial acceptance of the balance to be struck between intellectual property owners and users, or to a general subsidence in the importance of the separate entity principle due to the emergence of greater community expectations of company directors is unclear; it is most likely a combination of these factors at work. Corporations and intellectual property may be legal fictions, but their influence in today's commercial world is real and substantial - at moments when their principles and interests collide, balance, rather than primacy, is the key. 